\title{
Biodiversity of Sessile Fauna on Rocky Shores of Coastal Islands in Santa Catarina, Southern Brazil
}

\author{
Janayna L. Bouzon ${ }^{1, *}$, Fre de rico P. Brandini ${ }^{2}$, Ros ana M. Rocha ${ }^{1}$ \\ ${ }^{1}$ Department of Zoology, Federal University of Paraná, Curitiba, 81531-980, Brazil \\ ${ }^{2}$ Oceano graphic Institute, University of São Paulo, Butantã, 05508-120, Brazil
}

\begin{abstract}
The epilithic sessile fauna of coastal islands off Santa Catarina, southern Brazil, was analyzed along two 30 m long sublitoral transects. A total of 111 taxa were identified of which 55 are new records for the South Atlantic epilithic assemblages. Exotic sponges, bryozoans and ascidians (Paraleucilla magna, Schizoporella errata, Bugula dentata, Styela plicata respectively) were found at Marine Protected Areas. This paper gives further knowledge on the marine sessile fauna of the coastal islands of southern Brazil for environmental monitoring programs. A more complete list of epilithic species will certa inly provide a baseline to detect future environmental changes and local anthropogenic impacts on the biodiversity of southern Brazilian ecosystems.
\end{abstract}

Keywords Epilithic Fauna, New Records, Brazilian Islands

\section{Introduction}

The rocky shores off Santa Catarina, southern Brazil, extends for $562 \mathrm{Km}$ bordering the coastline of the mainland and 130 islands scattered from the Babitonga Bay until the southernmost limits of the main Santa Catarina Island[1]. The epilithic community of the sublitoral zones is rich and diverse, mostly dominated by sessile groups[2]. The Marine Biological Reserve of Arvoredo (REBIOMAR), the only Brazilian full marine protected area (MPA) in southern Brazil, occupies a polygon of 17,600 ha to protect sublitoral rocky environments of some islands and few submerged reefs, all fringed with a broad band of subtidal hard bottom communities. This MPA was set up in 1990 to ensure recruitment and recolonization ofadjacent areas which are permanently threaten by all kinds of anthropogenic impacts associated with the economic development along Santa Catarina coastal zone[3]. However, the proximity of the islands with the mainland threatens the biodiversity of their rocky habitats subject to the contamination of urban and industrial development in the last decades.

Due to the co-occurrence of a wide variety of organis ms and their trophic interactions, including symbiosis, the sessile benthic communities formed a specific rocky ecosystem with great heterogeneity of micro-habitats and, therefore, high bio logical richness [4,5].

The knowledge of the benthic invertebrate fauna in Brazil remains weak and the number of recorded species is much

\footnotetext{
* Corresponding author:

janayna.bouzon@gm ail.com (Janayna L. Bouzon)

Published online at http://journal.sapub.org/ms

Copyright (C) 2012 Scientific \& Academic Publishing. All Rights Reserved
}

lower than the world records, reflecting insufficient studies[3]. Studies on the biodiversity of sessile benthic invertebrates in Santa Catarina reports 32 species of Porifera[6-16], 14 Anthoathecata and Leptothecata hydrozoans [17-19], four octocorals [20,21], 34 ascidians [22]. In addition, 14 scleractinians anthozoans recorded at the outer continental shelf[23,24]. From a total of 346 species of bryozoans reported in Brazil, 40 from the Paraná coast, nearby our study site that were, however, never identified for in the epilithic assemblage of Santa Catarina[25].

An important factor to consider is presence and abundance of species considered invasive due to the fact that these organisms interfere in the survivability of other community species[26], plus the ability to generate economic and environmental damage, and in some cases to human health. Invasive organisms can cause marked changes in communities by altering the evolutionary pathway of native species by competitive exclusion site, niche displacement, hybridization, introgression, predation, and possibly extinction[27,28]. Together the introduction of exotic species, degradation and / or transformation of habitat, overexploitation of organis ms for consumption or ornaments, are the biggest threats to marine and coastal biodiversity.

Worldwide, the rate of degradation of natural coastal habitats has been faster than conservation initiatives. In Brazil the actual legal framework that supports conservation policies along the coast is poorly supported by ecological data[3]. This study aims to contribute for a better knowledge of the marine biodiversity in the State of Santa Catarina, with emphasis on cnidarians and bryozoans, in order to provide technical support for marine conservation in southern Brazil. 


\section{Study Area}

The region is in a transitional belt of latitudes between tropical and temperate regions, on the western boundary of the South Atlantic basin. Oceanographic conditions off southern Brazilian coast are strongly affected by the seas onal north-south displacement of the Subtropical Convergence. Onshore bottom intrusions of the oceanic South Atlantic Central Water (ACAS) along the Santa Catarina continental shelf in summer are due to north winds-induced Ekman transport of surface waters offshore, decreasing water temperatures at the bottom. In winter, winds are predominantly from south. They transport subantarctic waters of lower salinities, strongly affected by the outflow of the La Plata River. The hydrographic environment is therefore very dynamic during the annual cycle[29,30]. This affects the composition and the seasonal dynamics of regional epilithic assemblages [31,3].

The hard bottom of the islands is relatively shallow but physically heterogeneous, consisting of rounded rocks arranged in a delicate slope toward the sandy bottom. Large rocks form caves and walls up to about $15 \mathrm{~m}$ deep. The sublitoral cliffs at REBIOMAR, may extend beyond $30 \mathrm{~m}$ depth.

\section{Fieldwork}

Table 1. Characteristics of the Sampling Sites, Dives and Sampling Periods

\begin{tabular}{|c|c|c|c|}
\hline Islands & Sites & Dives & Date \\
\hline Graças & Paz Island & 2 & 02/04/2008 \\
\hline \multirow[t]{2}{*}{ Tamboretes } & In between islands & 1 & 03/04/2008 \\
\hline & South coast & 1 & 03/04/2008 \\
\hline \multirow[t]{2}{*}{ Galés } & Naufrágio da Lili & 2 & 07/03/2008 \\
\hline & Saco do Brás & 2 & 08/03/2008 \\
\hline Deserta & North site & 2 & $05 / 04 / 2008$ \\
\hline \multirow[t]{3}{*}{ Arvoredo } & Saco d’Água & 2 & $19 / 04 / 2008$ \\
\hline & Saco do Capim & 2 & 02/04/2008 \\
\hline & Saco do Capim & 1 & $19 / 04 / 2008$ \\
\hline \multirow[t]{3}{*}{ Campeche } & North site & 2 & $22 / 01 / 2008$ \\
\hline & South site & 2 & $14 / 01 / 2008$ \\
\hline & South site & 1 & $16 / 04 / 2008$ \\
\hline Três Irmãs & Imã do Meio & 1 & $17 / 04 / 2008$ \\
\hline \multirow{3}{*}{$\begin{array}{l}\text { Moleques do } \\
\text { Sul }\end{array}$} & South coast & 2 & 06/01/2008 \\
\hline & submerged rocky & 2 & 08/01/2008 \\
\hline & reef & 1 & $17 / 04 / 2008$ \\
\hline Total & & 26 & \\
\hline
\end{tabular}

Benthic assemblages were surveyed during 26 scuba dives between January and May 2008 (Table 1) a long two subtidal transects at 6 and $15 \mathrm{~m}$, in the following islands: Paz (Graças Archipelago, at $\left.26^{\circ} 10^{\prime} \mathrm{S} ; 48^{\circ} 29^{\prime} \mathrm{W}\right)$, Tamboretes $\left(26^{\circ} 22^{\prime} \mathrm{S}\right.$; $\left.48^{\circ} 31^{\prime} \mathrm{W}\right)$, Deserta, Galés, Arvoredo as part of the MPA of
Arvoredo (from $27^{\circ} 11^{\prime}$ to $27^{\circ} 16^{\prime} \mathrm{S}$; and $48^{\circ} 19^{\prime}$ to $48^{\circ} 24^{\prime} \mathrm{W}$ ), Campeche $\left(27^{\circ} 42^{\prime} \mathrm{S} ; \quad 48^{\circ} 27^{\prime} \mathrm{W}\right)$, Moleques do Sul

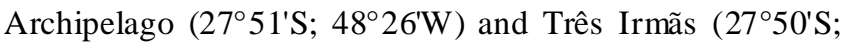
$\left.48^{\circ} 31^{\prime} \mathrm{W}\right)$ (Figure1).

The taxonomic composition and quantitative data on the epilithic commun ity were analy zed from manual collections of individual and pieces of colonial groups, with additional non-destructive photographic records were taken with digital camera Sony DSC-W90. Seven dives were exclusively dedicated to the inventory of hydrozoans, bryozoans and ascidians. The collected animals were anesthetized with menthol and fixed in formalin $4 \%$, except sponges that were fixed in $70 \%$ ethanol, for later identification in the laboratory.

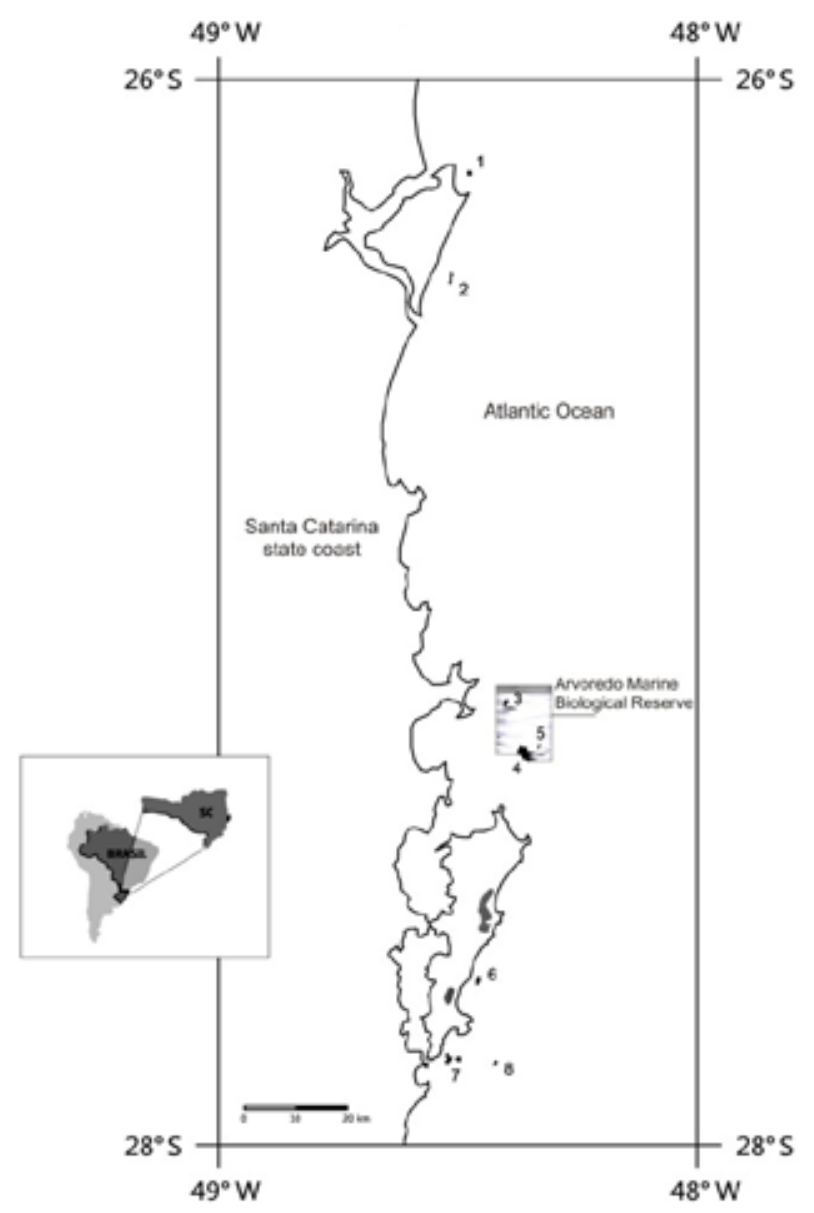

Figure 1. Map of the study area showing the coastal islands where benthic community was sampled. 1. Graças Archipelago; 2.Tamboretes Archipelago; 3.Galés Island; 4.Arvoredo Island; 5.Deserta Island; 6.Campeche Island; 7.Três Irmãs Islands; 8. Moleques do Sul Archipelago

All taxa were examine under stereomicroscope and separated in taxonomic groups to send to experts for identification. The Porifera specimens were deposited in the scientific collection of Rio Grande do Sul Zoo-Botanic Foundation. Cnidarians, bryozoans and ascidians were deposited in the scientific collection of Department of Zoology, Federal University of Paraná, Curitiba, Brazil (DZUP). 


\section{Results}

We have recorded 111 taxa belonging to the phyla Porifera, Cnidaria, Bryozoa, Entoprocta and Chordata (subphylum Tunicata, class Ascidiacea), distributed in 54 families, of which 27 taxa could not be identified at the specific level. The most representative groups were the Cnidaria with 38 hydrozoans and 11 anthozoans, followed by ascidians with 32 taxa, 18 sponges, 11 Bryozoa species and Entoprocta with only one not identified species (Table 2). Representatives of dominant sessile groups indentified during the sampling surveys can be seen in the photographic panels of Figures 2a (sponges), 2b (cnidarians) and 2c (ascidians and bryozoans).

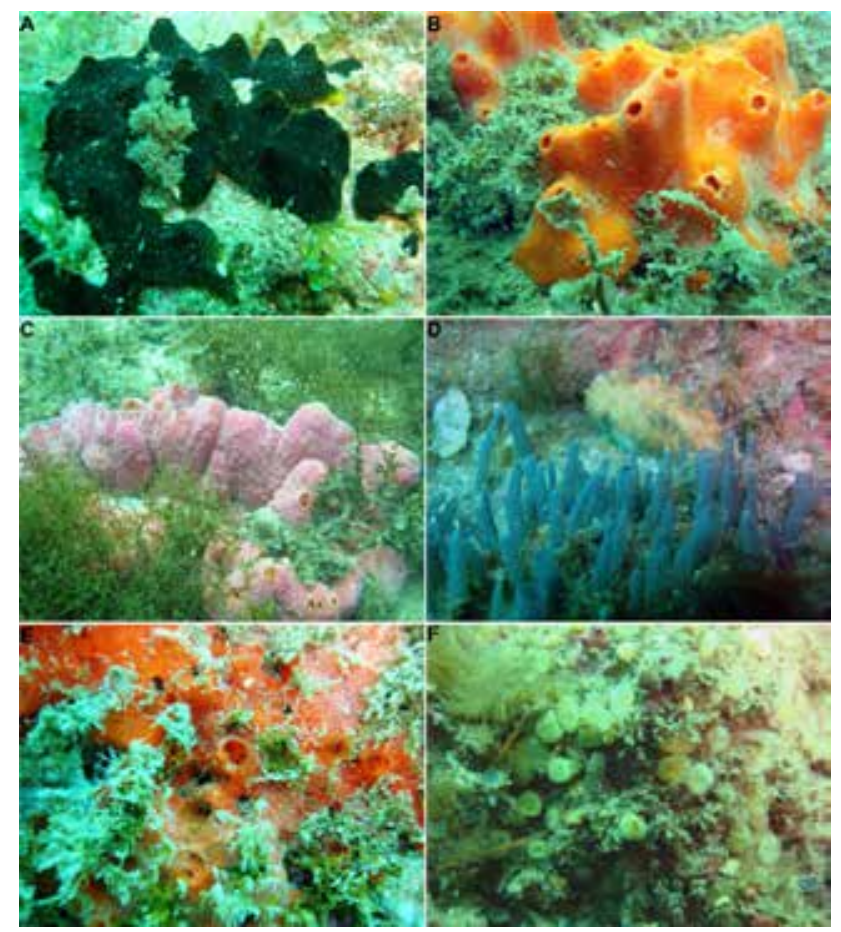

Figure 2a. Taxa of sponges of the Santa Cat arina coastal islands.Porifera: (A) Guitarra sepia, (B) Dragmacidon reticulatum, (C) Suberites aurantiacus, (D) Polymastia janeirensis, (E) Tedania ignis, (F) Clionacelata

Fifty five taxa are new records for Santa Catarina, which account for $50 \%$ of all specimens recorded. New records of species occurred for all phyla, but mainly in the Class Hydrozoa and the Phylum Bryozoa with 31 and 10 species, respectively. Five new Porifera, 4 Anthozoa and 5 ascidians were identified. The hydrozoans Lafoeina tenuis[32], Antennella secondaria[33], Sertularella rugosa[34] and Hincksella cylindrica[35], and the sea squirt Didemnum cf. calliginosum[36] have their geographic distribution expanded for the South Atlantic (Table 3).

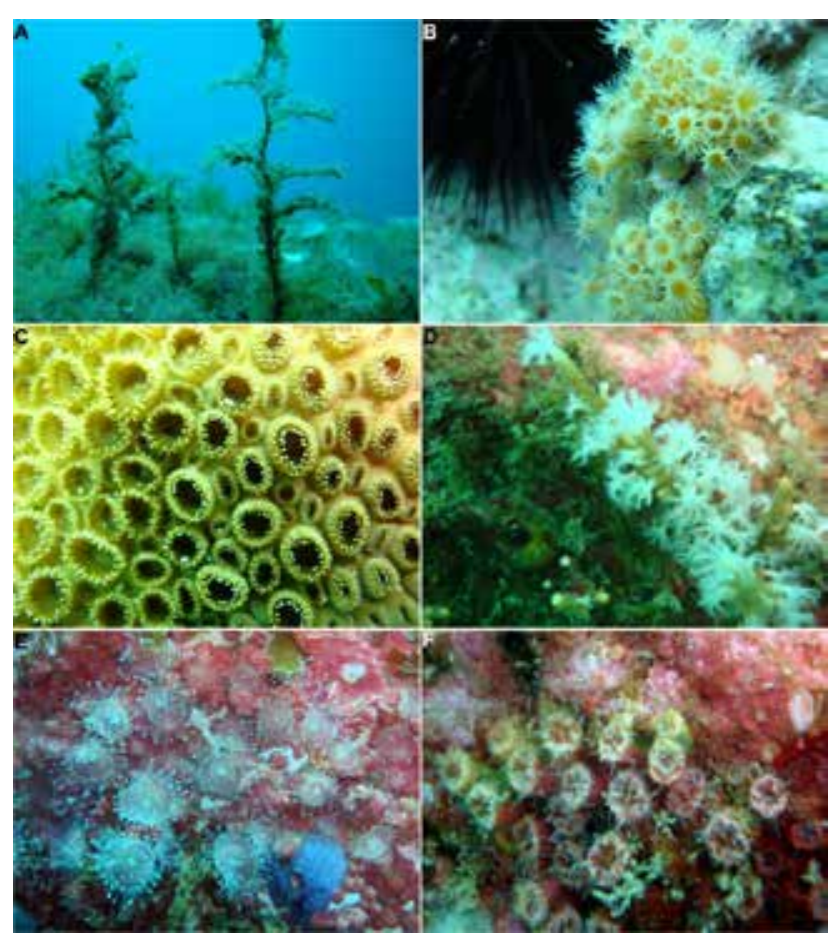

Figure 2b. Taxa of cnidariansof the Santa Catarina coastal islands.(A) Eudendrium cameum, (B) Parazoanthus sp., (C) Palythoa caribeorum (D) Carijoa riisei, , (E) Corynactis sp., (F) Astrangia rathbuni

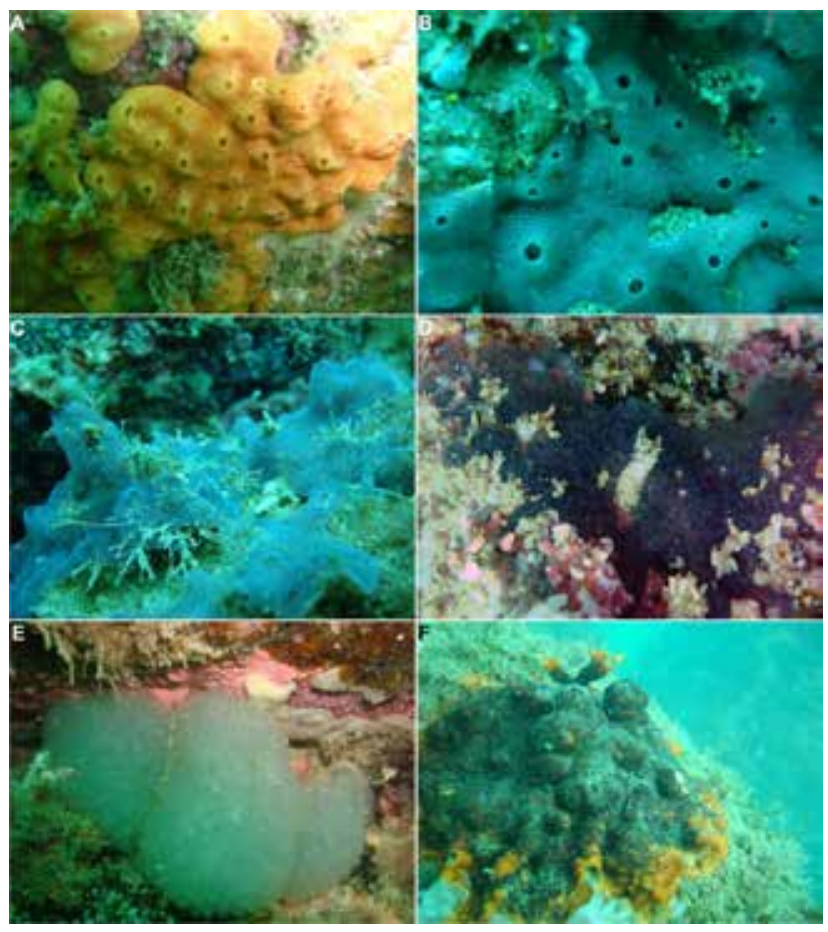

Figure 2c. Taxa of ascidians and bryozoans of the Santa Catarina coastal islands.Ascidiacea: (A) Didemnum granulatum, (B) Lissoclinum perforatum, (C) Diplosoma listerianum, (D) Distaplia bermudensis, (E) Euherdmania vitrea; Bryozoa: (F) Schyzoporella errata

Table 2. Taxa Identified from the Sublitoral Rocky Habitats of Santa Catarina Coastal Islands

\begin{tabular}{|c|c|c|c|c|c|c|c|c|c|}
\hline Classification & Taxa & Gra & Tam & Gal & Arv & Des & Cam & Msl & Irm \\
\hline PORIFERA & С & & & . & & & 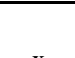 & . & . \\
\hline
\end{tabular}


Janayna L. Bouzon et al.: Biodiversity of Sessile Fauna on Rocky Shores of Coastal Islands in Santa Catarina, Southern Brazil

Suberitidae Polymastiidae

Trachycladidae Axinellidae

Dictyonellidae

Microcionidae Mycalidae

Guitarridae

Coelosphaeridae

Tedaniidae

Chalinidae

Amphoriscidae

Clathrinidae

CNIDARIA

HYDROZOA

Pennariidae

Bougainvilliidae

Eudendriidae

Aglaopheniidae

Campanulinidae

Haleciidae

Halopt erididae

Kirchenpaueriidae Lafoeidae

Plumulariidae

Sertulariidae

Syntheciidae Halopt erididae

Campanulariidae

ANT HOZOA

Clavulariidae

Paramuriceidae

Gorgoniidae

Ellisellidae

Rhizangiidae

Caryophylliidae Zoanthidae
Suberites aurantiacus (Duchassaing \& Michelotti, 1864)

Polymastia janeirensis (Boury-Esnault, 1973)

Trachycladus sp.

Dragmacidon reticulatum (Ridley \& Dendy, 1886) Axinellasp.

Scopalina ruetzleri (Wiedenmayer, 1977)

Arcanus sp.

Mycale (Cam ia) microsigmatosa Amdt, 1927 Mycale sp.

Guitarra sepia Lemer, Hajdu, Custodio \& van Soest, 2004

Lissodendorix isodictialys (Carter 1882)

Tedania ignis (Duchassaing \& Michelotti, 1864)

Haliclona mamm illaris Mothes \& Lerner, 1994 Haliclona sp.

Paraleucilla magna Klautau, Monteiro \& Borojevic, 2004 Clathrina aurea Solé-Clava, Klautau, Boury-Esnault, Borojevic \& Thorpe, 1991

Clathrina conifera Klautau \& Borojevic, 2001

Pennaria sp.

Bimeria vestita Wright 1859

Bougainvillia muscus (Allman, 1863)

Eudendrium sp.

Eudendrium cameum Clarke, 1882 n. id.

Aglaophenia latecarinata Allman 1887 Macrorhynchia philippina Kirchenpauer 1872 Macrorhynchia sp.

Lafoeina amirantensis (Millard \& Bouillon, 1973) Lafoeina tenuis G. O. Sars, 1874

Halecium dyssymetrum (Billard, 1929)

Antennella secundaria (Gmelin, 1791) Halopteris buskii (Bale, 1884)

Halopteris polymorpha (Billard, 1913)

Pycnotheca mirabilis (Allman, 1883)

Filellum serratum (Clarke, 1879) Filellum sp.

Monostaechas quadridens (McGrady, 1859)

Monotheca margaretta Nutting, 1900

Idiellana pristis Lamouroux, 1816

Dynamena quadridentata (Ellis \& Solander, 1786)

Dynamena disticha (Bosc, 1802)

Dynamena dalmasi (Versluys, 1899)

Thuiaria desmoides (Torrey, 1902)

Sertularella tenella (Alder, 1856)

Sertularella rugosa (Linnaeus, 1758)

Diphasia digitalis (Busk, 1852)

Diphasia tropica Nutting, 1904

Sertularia distans Lamouroux, 1816

Sertularia marginata (Kirchenpauer, 1864) Sertularia loculosa Busk, 1852

Sertularia turbinata (Lamouroux, 1816)

Hincksella cylindrica (Bale, 1888)

Halopteris diaphana (Heller, 1868)

Campanularia hincksii Alder, 1856

Clytia cf. gracilis (Sars, 1850)

Obelia dichotoma (Linnaeus, 1758)

Carijoa riisei (Duchassaing \& Michelotti, 1860)

Heterogorgia uatunami Castro, 1990

Leptogorgia punicea (Milne-Edwards \& Haime, 1857) Ellisella elongata (Pallas, 1766)

Astrangia rathbuni Vaughan, 1906

Phyllangia americana Milne Edwards \& Haime, 1849

Palythoa caribeorum (Duchassaing \& Michelotti, 1860) Protopalythoa variabilis (Duerden 1898)

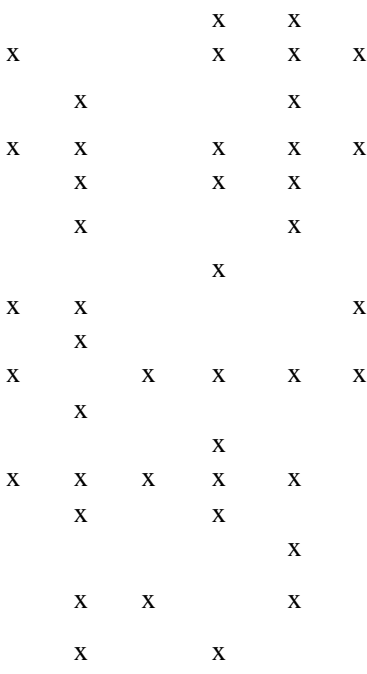

X $\quad \mathrm{X}$

$\mathrm{X}$

$\mathrm{x}$

$\mathrm{X}$

$\mathrm{X}$

$\mathrm{X} \quad \mathrm{X} \quad \mathrm{X}$

$\mathrm{X}$ 


\footnotetext{
Parazoanthidae Actiniidae

Corallimorpharia BRYOZOA

Ctenostomata

Alcyonidiidae

Vesiculariidae

Aeteidae

Bugulidae

Candidae

Lepraliellidae

Schizoporellidae

Crisuliporidae

ENTOPROCT A

CHORDATA

ASCIDIACEA

Perophoridae

Ascidiidae

Clavelinidae

Polycitoridae

Euherdmaniidae Polyclinidae

Polyclinidae

Holozoidae

Didemnidae
}

Styelidae
Parazoanthus sp.

Actinostella flosculifera (Lesueur, 1817) Corynactis sp

Ctenostomata sp.

Alcyonidium sp.

Amathia sp.

Zoobotryon verticillatum (delle Chiaje, 1828)

Aetea anguina (Linnaeus, 1758)

Bugula neritina (Linnaeus, 1758)

Bugula dentata (Lamouroux, 1816)

Caberea sp.

Celleporaria sp.

Schizoporella errata (Wat ers, 1878)

Crisulipora sp.

n. id.

Perophora regina Goodbody \& Cole, 1987 Ascidia tenue Monniot, 1983

Clavelina oblonga Herdman, 1880

Cystodytes dellechiajei (Della Valle, 1877)

Eudistoma clavatum Rocha \& Bonnet, 2009

Euherdmania vitrea Millar, 1961

Aplidium accarense (Millar, 1953) Aplidium sp.

Distaplia bermudensis Van Name, 1902

Diplosoma listerianum (Milne-Edwards, 1841) Diplosoma sp.

Lissoclinum fragile (Van Name, 1902)

Lissoclinum perforatum (Giard, 1872)

Didemnum ahu Monniot and Monniot, 1987

Didemnum cf. calliginosum Monniot, 1984

Didemnum cineraceum (Sluiter, 1898)

Didemnum granulatum Tokioka, 1954

Didemnum ligulum Monniot, 1983

Didemnum rodriguesi Rocha \& Monniot, 1993

Didemnum vanderhorsti Van Name, 1924

Didemnum sp1.

Didemnum sp2.

Didemnum sp3.

Didemnum sp4.

Leptoclinides latus Monniot, 1983

Leptoclinides sp.

Botrylloides nigrum (Herdman, 1886)

Botryllus tabori Rodrigues, 1962

Symplegma rubra Monniot, 1972

Symplegma sp.

Styela plicata (Lesueur, 1823) $\begin{array}{lll}\mathrm{x} & \mathrm{X} & \mathrm{x} \\ \mathrm{X} & \mathrm{X} & \end{array}$

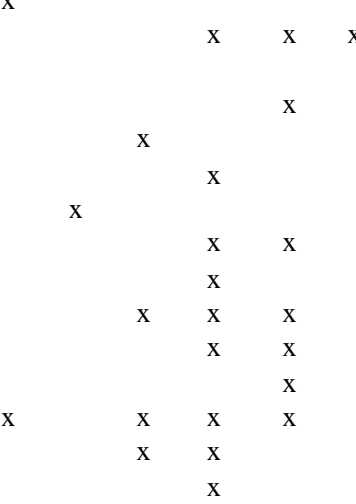

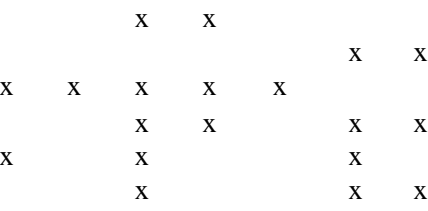

$\mathrm{X}$

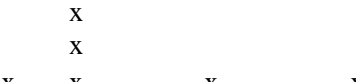

$\mathrm{X}-\mathrm{X}-\mathrm{X}$

$\mathrm{X}$
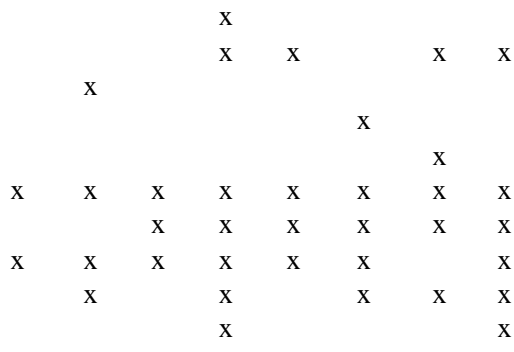

$\mathrm{X}$

$\mathrm{X}$

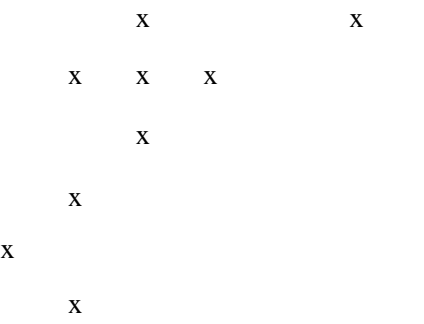

Pyuridae

Microcosmus exasperatus Heller, 1878

$\mathrm{X}$

Total

* GRA, Graças Archipelago; TAM, Tamboretes Archipelago; GAL, Galés Island; ARV, Arvoredo Island; DES, Deserta Island; CAM, Campeche Island; MSL, Moleques do Sul Archipelago; IRM, Três Irmãs Island; n. id., unidentified

The Porifera Arcanus sp., the Hydrozoa Macrorhynchia sp. and Filellum sp., the anthozoa genus Corynactis of the order Corallimorpharia, and the bryozoans genera Alcyonidium, Caberea, Celleporaria and Crisulipora are also new records for the Santa Catarina coastal assemblage, expanding their geographic limits.

The greatest richness of 57 species was observed at
Southern Moleques, with $47 \%$ of new records. Three hydrozoans (Hincksella cylindrica, Antennella secundaria e Sertularella rugosa) and the ascidian Didemnum $c f$. calliginosum are recorded for the first time in the South Atlantic with the southern limit of distribution at the Southern Moleques, south off Santa Catarina island. 
Table 3. New Occurrences of the Benthic Fauna of the Santa Catarina Islands and Previous Distribution of Taxa along the Brazilian Coast and the Southwestem Atlantic Ocean

\begin{tabular}{|c|c|c|}
\hline Taxa & New record & Previous distribution \\
\hline \multicolumn{3}{|l|}{ PORIFERA } \\
\hline Cliona celata Grant, 1826 & Southern Brazil & PE, BA, RJ, SP \\
\hline Arcanussp. & Southern Brazil & PE, RJ, SP \\
\hline Lissodendorix isodictialys (Carter 1882) & Southern Brazil & PE, SP \\
\hline Paraleucilla magna Klautau, Monteiro \& Borojevic, 2004 & Southern Brazil & RJ, SP \\
\hline Clathrina conifera Klautau \& Borojevic, 2001 & Southern Brazil & RJ \\
\hline \multicolumn{3}{|l|}{ HYDROZOA } \\
\hline Bimeria vestita Wright 1859 & Southern Brazil & BA, ES, SP \\
\hline Bougainvillia muscus (Allman, 1863) & SC & RJ - PR \\
\hline Macrorhynchia philippina Kirchenpauer 1872 & Southern Brazil & $\mathrm{PE}, \mathrm{BA}, \mathrm{RJ}, \mathrm{SP}$ \\
\hline Macrorhynchia sp. & Southern Brazil & $\mathrm{PE}, \mathrm{BA}, \mathrm{RJ}, \mathrm{SP}$ \\
\hline Lafoeina amirantensis (Millard \& Bouillon, 1973) & Southern Brazil & $\mathrm{PE}, \mathrm{RJ}$ \\
\hline Lafoeina tenuis G. O. Sars, 1874 & Western South Atlantic & South Florida, Bahamas \\
\hline Halecium dyssymetrum Billard, 1929 & Southern Brazil & ES, SP \\
\hline Antennella secundaria (Gmelin, 1791) & Western South Atlantic & Caribe \\
\hline Halopteris buskii (Bale, 1884) & Southern Brazil & SP \\
\hline Halopteris polymopha (Billard, 1913) & Southern Brazil & SP \\
\hline Pycnotheca mirabilis (Allman, 1883) & Santa Cat arina & RJ, SP \\
\hline Filellum serratum (Clarke, 1879) & Southern Brazil & SE, RJ, ES, Caribe \\
\hline Filellum sp. & Southern Brazil & SE, RJ, ES, Caribe \\
\hline Monostaechas quadridens (McGrady, 1859) & Southern Brazil & BA - SP \\
\hline Sertularia marginata (Kirchenpauer, 1864) & Southern Brazil & FN, PE, BA - PR \\
\hline Sertularia turbinata (Lamouroux, 1816) & SC & PE, ES - PR \\
\hline Sertularia loculosa Busk, 1852 & Southern Brazil & ES - SP \\
\hline Idiellana pristis Lamouroux, 1816 & Southern Brazil & BA, SP \\
\hline Dynamena quadridentata (Ellis \& Solander, 1786) & Southern Brazil & BA - SP \\
\hline Dynamena disticha (Bosc, 1802) & $\mathrm{SC}$ & FN, PE, BA - RS \\
\hline Thuiaria desmoides (Torrey, 1902) & Southern Brazil & Brasil \\
\hline Sertularella tenella (Alder, 1856) & Southern Brazil & RJ, Caribe \\
\hline Sertularella nugosa (Linnaeus, 1758) & Western South Atlantic & Europa, GL to NY, and NE of the OP \\
\hline Diphasia digitalis (Busk, 1852) & Southern Brazil & PE, BA, ES, SP \\
\hline Diphasia tropica Nutting, 1904 & Southern Brazil & ES - SP \\
\hline Dynamena dalmasi (Versluys, 1899) & Southern Brazil & $\mathrm{BA}, \mathrm{SP}$ \\
\hline Hincksella cylindrica (Bale, 1888) & Western South Atlantic & Caribe \\
\hline Halopteris diaphana (Heller, 1868) & SC & ES, SP, RS \\
\hline Campanularia hincksii Alder, 1856 & SC & $\begin{array}{c}\text { Cosmopolitan in shallow waters, except at } \\
\text { Ártico }\end{array}$ \\
\hline Clytia cf. gracilis (Sars, 1850) & SC & PE, SP, (ES- PR, RSlike C. hemisphaerica) \\
\hline Obelia dichotoma (Linnaeus, 1758) & SC & ES - PR, RS \\
\hline ANTHOZOA & & \\
\hline Phyllangia americana Milne Edwards \& Haime, 1849 & $\mathrm{SC}$ & CE - SP \\
\hline Palytho a caribaeorum (Duchassaing \& Michelotti, 1860) & Southern Brazil & CE, FN, Atol das Rocas, ASPSP, SP, \\
\hline Parazoanthus sp. & Southern Brazil & $\mathrm{RJ}$ \\
\hline $\begin{array}{l}\text { Corynactis sp. } \\
\text { BRYOZOA }\end{array}$ & Southern Brazil & RJ \\
\hline Alcyonidium sp. & SC & ES, SP, PR, RS \\
\hline Amathia sp. & $\mathrm{SC}$ & PE, AL, BA, ES, RJ, SP, PR \\
\hline Zoobotryon verticillatum (delle Chiaje, 1828) & Southern Brazil & $\mathrm{RJ}, \mathrm{SP}$ \\
\hline Aetea anguina (Linnaeus, 1758) & SC & PE, ES, RJ, SP,PR \\
\hline Bugula neritina (Linnaeus, 1758) & SC & RJ, SP, PR \\
\hline Bugula dentata (Lamouroux, 1816) & Southern Brazil & $\mathrm{PE}, \mathrm{ES}, \mathrm{RJ}$ \\
\hline Caberea sp. & Southern Brazil & SP, ES \\
\hline Celleporaria sp. & Southern Brazil & PE, BA, ES, SP \\
\hline Schizoporella errata (Waters, 1878) & Southern Brazil & SP \\
\hline Crisulipora sp. & Southern Brazil & SP \\
\hline ASCIDIACEA & & \\
\hline Didemnum cf. calliginosum Monniot, 1984 & South Atlantic & Caribe \\
\hline Didemnum cineraceum (Sluiter, 1898) & Southern Brazil & SP \\
\hline Ascidia tenue Monniot, 1983 & Southern Brazil & $\mathrm{BA}, \mathrm{SP}$ \\
\hline Botryllus tabori Rodrigues, 1962 & Southern Brazil & RJ, SP \\
\hline Symplegma rubra Monniot, 1972 & SC & $\mathrm{SP}, \mathrm{PR}$ \\
\hline
\end{tabular}

GL, Greenland; NY, New York; Oc, Ocean; OP, Pacific Ocean; ASPSP, São Pedro e São Paulo Archipelago; NE, Northeast. 
Arvoredo I. was the second in richness (42 species), with $24 \%$ of new records. This records percentage low is due probably to the previous samplings in Arvoredo I. The hydrozoan Lafoeina tenuis, previously described for southern Florida and the Bahamas[37], was identified in the Arvoredo and Deserta islands. These are their first records for the southwestern Atlantic.

Fifty-four percent of the species identified in the Graças Archipelago were new records, $75 \%$ of which are hydrozoans. On the Campeche island $48 \%$ are also new records (Figure 3) and all bryozoans recorded here in Santa Catarina coast represent also new records for the southern Brazilian coast. Seven taxa of Cheilostomata and four Ctenostomata were found among all.

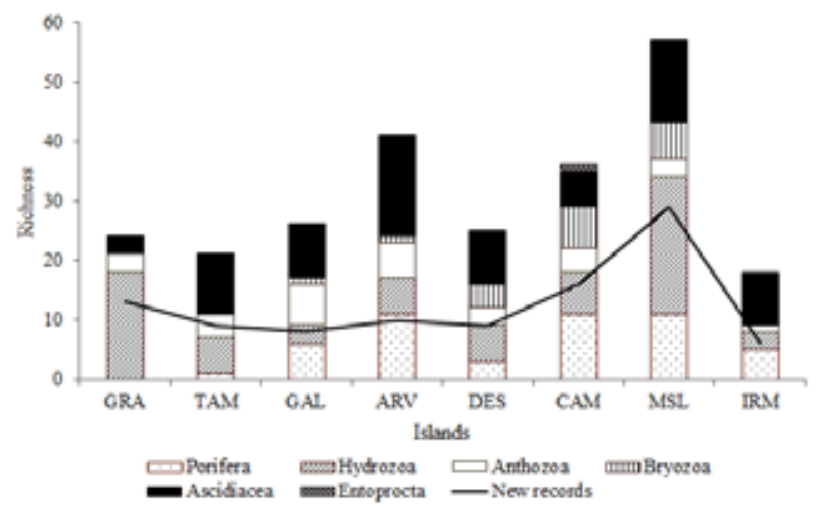

Figure 3. Species richness and new records of sessile benthic organisms to Santa Catarina state (GRA, Graças; TAM, Tamboretes; GAL, Galés; ARV, Arvoredo; DES, Deserta; CAM, Campeche ; MSL, Moleques do Sul; IRM, Irmãs). Note. There wasn't collection effort of the Phyllum Porifera in the GRA and TAM islands

\section{Discussion}

Biodiversity inventory is the first step for understanding ecological processes at coastal or even at broader oceanic scales. The remarkable number of new records of benthic fauna in Santa Catarina islands reveals the lack of taxonomic studies to better access the state of the marine conservation in the southern Brazilian coast. So far we have been unable to identify endangered species, due to the scarcity of data that might indicate even natural fluctuations of sessile invertebrate populations threatened by many anthropogenic impacts such as sedimentation associated with habitat losses at the coast, pollution and overfishing[38,39]. In general, a reef environment exposed to excessive loads of pollutants, responds to changes and often simplify the structure of biological communities[40]. Unfortunately, little is known on the effect of overfishing on the biodiversity in Brazilian subtidal reefs and rocky shores[41,42].

Among the new records for the South Atlantic the sea squirt Didemnum cf. calliginosum, originally described by[43] on the Caribbean island of Guadeloupe, had its distributional range extended to the State of Santa Catarina, more exactly on the Campeche I. The ascidian commun ity in Brazil is typically tropical with little overlap with the
Argentina and Patagonia fauna[44]. The presence of these species in Santa Catarina state subtropical waters is probably due to the multiple introductions of the species in the southern coasts $[45,46]$ where major harbor facilities are located. The lack of historical records prevents us from defining the status of many species that rema in cryptogenic, but we believe the development of molecular studies of global scope will reveal invasion of exotic species in the western Atlantic, some of them already recorded in Brazilian waters. According to[47] there are forty species of exotic zoobenthos along the Brazilian coast, twelve of which are sessile animals. In the coastal islands off Santa Catarina four species of his list of exotic zoobenthos were identified. For instance, the invasive sea squirt Styela plicatawas first recorded to Brazil at Rio de Janeiro[47]. The type specimen was from Philadephia and some authors consider S. plicata as widely distributed species along the warmer coast of Atlantic, Pacific and Indian Ocean and also Mediterranean Sea[48]. Here it was found within the MPA of Arvoredo and Galés Is. Dense aggregates of this species are formed at the sublitoral of Santa Catarina Is. where each individual takes an elongated shape with a stalk of attachment. In southern Brazil, it is rarely found in the natural environment, preferring strings of mariculture grounds and floating artificial substrates of harbour facilities[49]. Yet, it was first recorded in a natural rocky shore of Santa Catarina.

The calcareous sponge Paraleucilla magna[50]has an undefined status about native or exotic specie status. $P$. magna has been found along the Brazilian coast and it was found in the Moleques do Sul and Aranhas archipelagos, in the northern coast of the Santa Catarina island (Bouzon, personal observation). She is a cryptogenic specie (Cavalcanti, personal co mmun ication), i.e., cause we cannot say whether it is native or exotic specie. It has a full life cycle in nature and evidence of population increase over time, but without apparent environmental or socioeconomic impact. The exotic bryozoan Schizoporella errata(Figure 2c) while Bugula dentata were commonly found in the islands. The first is an established species and B. dentata is present in the natural environment but without further increase in abundance and distribution[46]. However, since we found it in reasonable abundance in the islands of Santa Catarina as well as in the coast off Cabo Frio, Rio de Janeiro the status of this exotic species in Brazil should be reviewed because we considered it considered already established.

Distributional limits of the northern Brazilian tropical sessile fauna were extended southwards in our records. Subtropical provinces of the southeastern and southern Brazil have been regarded as a transitional zone for the temperate fauna of the western Atlantic[51]. However, the study area belongs to the Paulista Province[52] where ca $40 \%$ of the records which are also found along other sections of the Brazilian coast were endemic to it. This province extends from the Espírito Santo to Rio Grande do Sul ( from $22^{\circ}$ to $32^{\circ} \mathrm{S}$ ) and is characterized by high incidence of endemic species, and can expect a s mall difference in species composition across the province, with the predominance of 
tropical species to the north and temperate species to the south. Nevertheless, besides low temperatures in southern Brazil during winter time, the lacking of rocky shores further south fro m Santa Catarina represents an additional barrier for the dispersal of epilithic organis ms.

The taxonomic analyses of the sessile fauna here described for the southernmost islands off Florianópolis have demonstrated they are equally or even more diverse than the assemblages of the islands of the Arvoredo MPA in the northern coast of Santa Catarina. Hence it should also be protected. This study has improved substantially the knowledge on the marine biodiversity in the coastal zone of Santa Catarina state. We hope it will contribute for the development of a more technically oriented conservation policy for the coastal ecosystems of southern Brazil.

\section{ACKNOWLEDGEMENTS}

We would like to thank the contributors MSc. João Luís Carraro and Dra. Beatriz Mothes of the Porifera Marine Laboratory of the Natural Sciences Museum of the Zoobotanic Foundation of Rio Grande do Sul to identification of the sponges, Dra. Maria Angélica Haddad and students Ana Caroline Cabral, Halina L. Heyse and Júlia Beneti of the Biology Laboratoryof the Hydrozoans and Bryo zoans of the Universidade Federal do Paraná (UFPR) to identification of the cnidarians and bryozoans, and the MSc. Thais Miranda and Dr. Antônio Carlos Marques of Medusozoa Laboratoryof the Universidade do Estado de São Paulo to the identification and confirmation of hydrozoans species. We also thank Laura P. Kremer and Rafael Metri for their help in field work. Field trips were funded by $\mathrm{CNPq}$ (grant number 475367/2006-5 to S.R. Floeter; 474566/2007-2 to R. M. Rocha). CNPq also awarded PhD scholarship to J.L. Bouzon (141398/2007-8).

\section{REFERENCES}

[1] Gaplan,1986, Atlas de Santa Catarina. Rio de Janeiro. Aerofoto Cruzeiro.

[2] Mazzer, A. M., 2002, Aspectos da geografia física das ilhas costeiras catarinenses. Florianópolis. Anais do Simpósio: Ilhas Costeiras e Ilhas Oceânicas.

[3] Amaral, A. C. Z., and Jablonski, S., 2005,Conservação da biodiversidade marinha e costeira no Brasil. Megadiversidade 1, 43-51.

[4] Ribeiro, S. M, Omena, E. P., and Muricy, G., 2003, Macrofauna associated to Mycale microsigmatosa (Porifera, Demospongiae) in Rio de Janeiro State, SE Brazil. EstCoastShelfSci. 57, 951-959.

[5] Henkel, T.P., and Pawlick, J.R., 2005, Habitat use by sponge-dwelling brittlestars. Mar Biol 146, 301-313.

[6] Volkmer-Ribeiro, C.,andMothes-de-Moraes, B. 1975,Esponjas tetraxonidas do litoral sul-brasileiro. I -
Redescrição de Cydoniumglariosus Sollas, 1886 e Erylusformosus Sollas, 1886. Iheringia 47, 3-22.

[7] Mothes-de-Moraes, B., 1985,Primeiro registro de Myriastra purpurea (Ridley, 1884) para a costa brasileira (Porifera, Demospongiae).Rev. Bras. Zool. 2, 321-326.

[8] Mothes, B., and Lerner, C.B., 1994, Esponjas marinhas do infralitoral de Bombinhas (Santa Catarina, Brasil) com descrição de três espécies novas (Porifera: Calcarea e Demospongiae). Biociências 2, 47-62.

[9] Lerner, C. B., 1996, Esponjas da Ilha da Galé, Reserva Marinha Biológica da Ilha do Arvoredo, Santa Catarina, Brasil (Porifera; Desmospongiae). Biociências 4, 101-129.

[10] Lerner, C. B. and Hajdu, E., 2002,Two new Mycale (Naviculina)(Mycalidae, Poecilosclerida, Demospongiae) from the Paulista Biogeographic Province (SW Atlantic). Rev. Bras. Zool. 19, 109-122.

[11] Carvalho, M.A., Carraro, J.L., Lerner, C.B. and Hajdu, E., 2003,First Record of Ciocalypta (Demospongiae: Halichondrida) from Brazil, Southwestern Atlantic,with description of a new valid species. Zootaxa 302, 1-8.

[12] Lerner, C. B., Hajdu, E., Custódio, M. and Soest, R. Van., 2004,Guitarra sepia n.sp. from the southwestern Atlantic (Demosp ongiae, Poecilosclerida, Guitarridae). First record of a Guitarra without placochelae. Bollettino dei Musei e degli Istituti biologici dell' Universitá di Genova. Genova 68, 405-411.

[13] Lerner, C. B., Mothes, B., and Carraro, J.L., 2005, Novos registros e ampliação de limites meridionais de distribuição de poríferos (Porifera, Demospongiae) no Atlântico sudoeste. Ver. Bras. Zool. 22, 596-612.

[14] Lerner, C.B., Carraro, J. L., and Soest, R. V., 2006, Raspailia (Raspaxilla) bouryesnaultae, a new name for Brazilian Raspaxilla elegans Boury-Esnault, 1973 (Demospongiae, Poecilosclerida, Raspailiidae) with a redescription and a new record. Zootaxa 1129, 37-45.

[15] Mothes, B., Kasper, G. L., Lerner, C. B., Campos, M., and Carraro, J.L., 2006,Spongia (Heterofibria) catarinensis sp. nov. (Porifera, Spongiidae) no litoral de Santa Catarina, Brasil. Iheringia 96, 335-338.

[16] Mothes, B., Campos, M. A., Eckert, R. A. and Lerner, C. B., 2008, Latrunculia (Latrunculia) verticillata sp. nov. (Porifera, Poecilosclerida, Latruncullidae) fron the bathyal region off the coast of Santa Catarina State, Brazil, Southwestern Atlantic. Zootaxa 1744, 59-65.

[17] Migotto, A.E., 1996, Benthic Shallow - water hydroids (Cnidaria, Hydrozoa) of coast São Sebastião, Brazil, including a checklist of Brazilian hydroids. Zool. Verhand elingen 306, 1-125.

[18] Migotto A.E., Marques A.C., Morandini, A.C. and da Silveira, F.L., 2002, Checklist of the Cnidaria Medusozoa of Brazil, Biota Neotrop. 2, 1-31.

[19] Marques, A.C., Morandini, A.C., and Migotto, A.E.,2003,Synopsis of knowledge on Cnidaria Medusozoa from Brazil. Biota Neotrop. 3, 1-18.

[20] Castro, C.B., Echeverría, C.A., Pires, D.O., and Fonseca, C.G., 1999, Distribuição do bentos (Cnidaria e Echinodermata) em costões rochosos da Baía de Ilha Grande, 
Rio de Janeiro, Brasil. In Silva SHG \& Lavrado HP (Eds). Ecologia dos Ambientes Costeiros do Estado do Rio de Janeiro. Série Oecol. Bras. VII, Rio de Janeiro, Brasil.

[21] Castro, C.B., Medeiros, M.S. and Loiola, L.L., 2010,Octocorallia (Cnidaria: Anthozoa) from Brazilian reefs. Jour. Nat. Hist. 44, 763-827.

[22] Rocha, R. M., Moreno, T. R.,and Metri, R., 2005, Ascídias da Reserva Biológica Marinha do Arvoredo, SC. Rev. Bras. Zool.22, 461-476.

[23] Laborel, J., 1969, Madreporaires et hydrocoralliair es récifaux des côtes Brasiliennes. Systématic, écologie, répartition verticale et geographique. Annales de l'Institut Oceanographique Paris 47, 171-229

[24] Kitahara, M.V., 2006,Novas ocorrências de corais azooxantelados (Anthozoa, Scleractinia) na plataforma e talude continental do sul do Brasil (25-34 $\left.{ }^{\circ} \mathrm{S}\right)$. Biotemas 19, $55-63$.

[25] Vieira, L.M., Migotto, A.E., and Winston, J.E., 2008, Synopsis and annotated checklist of recent marine Bryozoa from Brazil. Zootaxa1810, 1-39.

[26] Elliott, M., 2003, Biological pollutants and biological pollution an increasing cause of concern. Mar. Poll. Bull. 46, 275-280.

[27] Mooney, H.A., and Cleland, E.E., 2001,The evolutionary impact of invasive species. Proc. Natl. Acad. Sci. 98, 5446-5451.

[28] Lotze, H.K., Lenihan, H.S., Bourque, B.J., Bradbury, R.H., Cooke, R.G., Kay, M.C.,Susan, M. Kidwell, S.M., Kirby, M.X., Peterson, C.H. and Jackson, J.B.C., 2006,Depletion, degradation, andrecovery potential of estuariesand coastal seas. Science 312, 1806-1809.

[29] Castro, B.M., and Miranda, L.B., 1998, Physical oceanography of the western Atlantic continental shelf located between $48 \mathrm{~N}$ and $348 \mathrm{~S}$. In Robinson A.R. and Brink K.H. (eds) The sea. New York: John Wiley and Sons, pp. 209-251.

[30] Seeliger, U., Odebrecht, C. and Castello, J.P.,1997, Subtropical convergence environments: the coast and sea in the southwestern Atlantic. Berlin: Springer.

[31] Borzone, C. A., Pezzuto, P. R., and Marone, E., 1999, Oceanographic Characteristics of a Multi-Specific Fishing Ground of the Central South Brazil Bight. Mar. Ecol. 20, 131-146.

[32] Sars, G.O., 1874, Bidrag til Kundskaben om Norges Hydroider. Forhandlinger i Videnskabsselskabet i Kristianina. 91-150, pls 2-6.

[33] Gmelin, J.F., 1791, C. Linnaeus, Systemae naturae. Thirteenth edition, edited by J.F. Gmelin. Vol. 1, part 6 (Vermes): 30213910. Lipsiae, G. E. Beer.

[34] Linnaeus, C., 1758, Systema naturae per regna tria naturae, secundum classes, ordines, genera, species cum characteribus, differentiis, synonymis, locis. Editio decima, reformata: 1-823. Holmiae (Stockholm), L. Salvii.

[35] Bale, W.M., 1888. On some new and rare Hydroida in the Australian Museum collections. Proc. Linn. Soc. N.S.W.
(2)3(2): 745-799, pis 12-21.

[36] Monniot, C., and Monniot, F., 1984, Ascidies littorals de Guadeloupe. 7. Espèces nouvelles et complementaries a l'inventaire. Bull. Mus. Nat. Hist. Nat.Ser. 4, A, 6(3):567-582.

[37] Vervoort, W., 1967,Report on a collection of hydroida from the caribbean region, including an annotated checklist of caribbean hydroids. Zool. Verhandelingen 92, 1-122.

[38] Maughan, B. C.,2001,The effects of sedimentation and light on recruitment and development of a temperate, subtidal, epifaunal community. Jour. Exp. Mar. Biol. Ecol. 256, 59-71.

[39] Maldonado, M., Giraud K., and Carmona, C.,2008,Efects of sediment on the survival of asexually produced sponge recruits. Mar. Biol.154, 631-641.

[40] Lobban, C.H., and Harrison, P.J.,1994, Seaweed ecology and physiology. Cambridge University press. United Kingdom.

[41] Floeter, S. R., Halpern, B. S. and Ferreira, C. E. L.,2006,Effects of fishing and protection on Brazilian reef fishes. Biol. Cons. 128: 391-402.

[42] Ferreira, B. P., and Maida, M. ,2006, Monitoramento dos Recifes de Corais do Brasil, situação atual e perspectivas. Ministério do Meio Ambiente 120 pp.

[43] Rodrigues, S.A., Lotufo, T. and Rocha, R.M., 1999, Classe Ascidiacea. In: Migotto, A.E. and Tiago, C.G. (Eds.), Biodiversidade do Estado de São Paulo, Brasil. Síntese do conhecimento ao final do século XX: 3 - Invertebrados marinhos.FAPESP, São Paulo.

[44] Rocha, R.M., Kremer, L.P., Baptista, M.S. and Metri, R., 2009, Bivalve cultures provide habitat for exotic tunicates in southern Brazil. Aquat. Inv. 4: 195-205.

[45] Rocha, R. M., Muniz, G. M. and Lotufo, T.M.C., 2011, Checklist das ascídias do Estado de São Paulo. Biota Neotrop. 11(1a).

[46] Lopes, R.M., 2009, Informe sobre as Espécies Exóticas Invasoras Marinhas no Brasil. Brasília, Ministério do Meio Ambiente, Série Biodiversidade 33, 439 p.

[47] Barros, R. C., Rocha, R. M. and Pie M. R., 2009, Humanmediated global dispersion of Styela plicata (Tunicata, Ascidiacea). Aquat. Inv. 4, 45-57.

[48] Van Name, W.G., 1945, The North and South American Ascidians. Bull. Am. Mus.Nat. Hist. 84. New York. 520p.

[49] Floeter, S. R., Soares-Gomes, A., and Hajdu, E., 2009, Biogeografia Marinha. In: Pereira, R. C. and Soares-Gomes, A. (Orgs.). Biologia Marinha. Editora Interciência, Rio de Janeiro, $2^{\mathrm{a}}$ edição, pp. 421-441.

[50] Klautau. M.. Monteiro. L. and Boroievic R. 2004. First occurrence of the genus Paraleucilla (Calcarea. Porifera) in the Atlantic Ocean: P. magna sp. nov. Zootaxa, 710, 1-8.

[51] Laborel, J., 1969, Madreporaires et hydrocoralliaires récifaux des côtes Brasiliennes. Systématic, écologie, répartition verticale et geographique. Ann. Inst. Oceanogr.(Paris)47, $171-229$.

[52] Palácio, F. J., 1982,Revisión Zoogeográfica Marina Del SurDel Brasil. Bol. Inst. Oceanog. 31, 69-92. 